\title{
UTILIZATION OF ORGANIC SOILS IN PUERTO RICO
}

\section{A. LUGO-LÓPEZ AND J. A. BONNET}

\section{INTRODUCTION}

In Puerto Rico, as in the world as a whole, soils are mostly of a mineral nature with small, varying quantities of organic constituents. This organic fraction, however, is so important that the term "organic soils" has been used in connection with those in which the organic matter content is above 15 percent in contrast to "mineral soils" wherein the organic constituents are decidedly less. There are more than 25,000 acres of organic lands in Puerto Rico that still lie untilled, mostly because of very poor natural drainage, complicated sometimes, by the presence of harmful alkali salts in the profile. When properly drained and managed these peats and muck lands perhaps will rank among the most productive soils of the Island.

Zerban $(12)^{2}$ studied, the salt marshes of the north coasts of Puerto Rico in a preliminary way. His main objective was to determine the endurance limit of cane grown under various saline levels at different places. Bartel (2) established a basis for the selection of pumps to drain the coastal swamps of Puerto Rico by using drainage coefficients based on rainfallfrequency studies. Gruz Monclova (5) conducted preliminary work on soil salinity at the Guánica, Aguirre, Lafayette, and Tiburones areas. Dachnowski-Stokes and Roberts (6) reported morphological studies of several saline peat profiles of Puerto Rico.

Organic lands present problems of soil management quite distinct from those of mineral soils. Their reclamation is expensive. Their ground water table has to be lowered to a level where it will allow adequate aeration for successful crop production. The harmful alkali salts, if any, must be leached. This can be accomplished through drainage-tiles, ditches, pumps, dams, and other devices required to control the ground waters; with chemicals such as sulfur and gypsum, and by irrigation with fresh waters to leach out the toxic salts. However, experience from other areas seems to indicate that the productive capacity of these lands will justify economically the expenditures required. Such has been the case of the Fens of England, the "veens" of Holland, the Everglades of Florida, and the muck lands of Michigan, Minnesota, New York, and other areas $(1,7,8)$. To the Island of Puerto Rico with its extremely meager land resources, the reclamation has still greater meaning: It will provide more food for the population, more income for the Government, more trade volume, and more wealth.

\footnotetext{
${ }^{1}$ Associate Soil Scientist, and Head, Soils Department, respectively, Agricultural Experiment Station, University of Puerto Rico, Río Piedras, P. R.

${ }^{2}$ Figures in parentheses refer to Literature Cited, p. 65.
} 


\section{ORIGIN OF ORGANIC SOILS IN PUERTO RICO}

Organic soils have been formed from the accumulation of leaves, twigs, roots, and other materials in lagoons and bays. Dachnowski-Stokes and Roberts (6) report two types of peat in Puerto Rico: The Ensenada Honda peat, and the Martin Peña peat, and one type of muck, the Caño Tiburones muck. The first peat consists of one continuous layer of mangrove peat, and the second of two layers: A surface fibrous mangrove peat over a layer of marine sedimentary peat. The muck consists also of two layers: An upper sedimentary muck over a tule peat.

A monolithic sample of the Ensenada Honda peat, collected about 2 $\mathrm{km}$. east of Ensenada Honda, at the east coast of Puerto Rico, is described by Dachnowski-Stokes and Roberts (6) as follows:

"Mangrove peat: 0 to $101.6 \mathrm{~cm}$. brown to reddish-brown, coarse but firm fibrous peat, consisting chiefly of a porous, interlacing network of fine rootlets, yellowishbrown in color, brittle when dry, crumbling into small particles. Embedded in the tangle of rootlets are relatively small quantities of dark colored, finely divided organic sediments carried by tides and waves of sea water. A prominent feature is considerable amounts of stout roots of mangrove, the pith of which is in varying states of decomposition. The whole profile section is indistinctly differentiated, free from woody fragments and plant remains of secondary species, contains little material and is but feebly altered by soil making processes; it is the product of the roots and rootlets from a pure stand of mangrove. Soluble salts are present in the entire profile in amounts ranging between 3 and 5.5 per cent and the reaction of the air-dried material is strongly acid ( $\mathrm{pH} 4.3-4.6$ ). The thickness of the layer varies in places from 1 to $1.5 \mathrm{~m}$. and rests abruptly on coarse white sand of unknown depth."

A profile of the Martín Peña peat, collected about $1.5 \mathrm{~km}$. east of the Martín Peña railroad station, at Río Piedras, is described (6) as follows:

\footnotetext{
"Mangrove peat: 0 to $28 \mathrm{~cm}$; thin surface cover of black, sticky organic tidal ooze containing an occasional mollusk shell; the sediment varies in thickness from $5 \mathrm{~mm}$. to $1.5 \mathrm{~cm}$. Below it is reddish-brown, coarsely, fibrous, matted mangrove peat which consists of a tangle of yellowish colored fine rootlets and large reddish-brown pithy aerial and lateral roots of mangrove (species of Rhizophora and Avicennia) embedded in black, finely divided organic residue. The material contains about 3 per cent of soluble salts and has a moderately acid reaction ( $\mathrm{pH} 5.6$ ).

" 28 to $61 \mathrm{~cm}$. ; finely fibered, very dark brown to mottled, more or less firm mangrove peat; it consists of a large proportion of black organic residue held in a meshwork of fine yellowish rootlets and is penetrated by a few stout, branching pithy roots in varying states of decomposition.

The material is saline and acid ( $\mathrm{pH}$ 5.1).

"Sedimentary peat: 61 to $92 \mathrm{~cm}$.; grayish-black, soft, oozy mixture composed chiefly of organic residue of the size of colloidal particles, together with gray colored fine rootlets. The layer is penetrated by a few pithy roots of mangrove; it becomes dense and hard when dry and breaks with smooth fractures. The content of soluble salts varies between 3 and 3.5 per cent and the reaction is moderately acid ( $\mathrm{pH} 5.6$ ).

"At a depth ranging from 1 to $1.5 \mathrm{~m}$., the underlying mineral soil is bluish green to gray plastic clay.”
} 
A profile of Caño Tiburones muck collected from the eastern part of Caño Tiburones swamp, about $15 \mathrm{~km}$. east of Arecibo, is described (6) as follows:

"Sedimentary muck: 0 to $26 \mathrm{~cm}$.; under cultivation; the material at the surface develops a black, granular muck, more or less mineralized; it contains insects and worms. Downward it continues into sticky plastic sedimentary peat of heavy texture, dense, compact and hard when dry, tending to break into angular cloddy aggregates that later disintegrate into loose granules. The cultivated material is neutral in reaction $(\mathrm{pH} 7.3)$.

"Tule peat: 26 to $58 \mathrm{~cm}$; black, stringy fibrous peat consisting mainly of soft, partly decomposed vertical stems and the rootstocks of tule (Scirpus sp., Eleocharis sp. and others), embedded in sticky plastic organic residue derived from secondary herbaceous plants. The material contains very small amounts of soluble salts, is slightly acid in reaction ( $\mathrm{pH}$ 5.9) and shows a tendency to compaction and hardening when dry.

" 58 to $63 \mathrm{~cm} .:$ band of dark gray clayey mineral material probably due to flood water; it is mottled with black organic residue and channeled vertically with partly decomposed, flattened culms of tule sedges (Scirpus sp.); the material is moderately saline and acid in reaction.

" 63 to $90 \mathrm{~cm}$.: coarse stringy-fibrous tule peat, very dark brown to black, consisting largely of vertical, partly decomposed, more or less flattened stems of tule (Scirpus sp.) in a matrix of plastic amorphous organic residue. No visible alterations have taken place in the material during the period of time it has been buried by the mineral sediments. The content of soluble salts is fairly high, and the reaction is strongly acid $(\mathrm{pH} 4.2)$. The thickness of the layer extends to a depth of $1 \frac{1}{2} \mathrm{~m}$. below the surface and the underlying mineral material is a bluish-gray, plastic clay."

Dachnowski-Stokes and Roberts (6) say:

"It is apparent that Caño Tiburones first developed as a marsh characterized by fresh or brackish water in which tall-stemmed rushes (Scirpus sp.) were dominant and persisted in great abundance as the pioneer plant community. The profile section also indicates a sudden inflow of erosion water that carried with it large quantities of clayey sediments. Flooding, that may be attributed to a period of very moist climatic conditions, or else subsidence, appears to have continued down to recent times. The change brought about a stand of water so nearly fresh that aquatic vegetation, forming sedimentary peat, replaced the tule marsh. The vegetation dominating at the present time is associated in places with saline conditions due to the entrance of tide water, but no particular part of it has, as yet, contributed to the development of fibrous peat."

\section{DISTRIBUTION}

The organic soils, called either Bogs or Half-Bogs, depending on the depth of the organic layers, are confined to the coastal lowlands of the Island. They are waterlogged most of the year because of their topographic position and their proximity to the oceanic waters. The characteristic vegetation consists of mangroves, sawgrass, sedges, cattails, reeds, ferns, and similar types of water-loving plants. Table 1 shows the series of organic soils of Puerto Rico and their extent in acres. 
Twenty-four percent of the organic lands have been classed as Tiburones muck. The most extensive belt of this soil occurs in northern Puerto Rico in the Arecibo-Barceloneta region where the average rainfall fluctuates around 60 inches per annum. Other areas are found north of Central Canóvanas, and near Lago Tortuguero. Slightly over 3 percent of the area has been reclaimed and is being cultivated. Under the farm practices of the region, yields of 45 tons of ratoon cane have been obtained, averaging about 8 to 10 percent of sucrose. Good yields of cabbage have been obtained on a very limited acreage. Some areas are devoted to forage crops and the amount of malojillo produced is quite acceptable. In certain areas alkali salts are found in harmful concentrations - the surface soil at times showing a white crust of salts during dry periods. This mostly results from flooding by sea water in the extremely low places, particularly during high tides when the outlet of the old "Caño Tiburones" remains clogged for relatively long periods.

Table 1.-Distribution of organic soils in Puerto Rico

\begin{tabular}{|c|c|c|}
\hline Soil series & Soil group & Acres \\
\hline Tiburones muck.. & Bog & 6,848 \\
\hline Saladar muck..... & do. & 8,000 \\
\hline Saladar muck, shallow phase... & Half-Bog & 1,152 \\
\hline Peat.................. & Bog & 7,360 \\
\hline Peat, shallow phase................ & Half-Bog & 1,280 \\
\hline 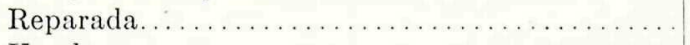 & do. & 2,560 \\
\hline Ursula............................. & do. & 1,088 \\
\hline Total. & & 28,180 \\
\hline
\end{tabular}

Saladar muck, considered together with its shallow phase, is the most extensive bog soil of the Island. It occurs in narrow strips along the north, east and west coasts under various local climatic belts: In Mandry (east of Central Pasto Viejo, Humacao), Puerto Nuevo, Toa Baja, east of San Juan, east of Arroyo, Guanajibo, Boquerón (near Laguna Rincón), southeast of Fajardo, northwest of Isabela, and in a number of other places. Small areas are planted to sugarcane near Arroyo in the southeast, and in Mandry in the east, but for the most part the land is not being used agriculturally. Toxic quantities of alkali salts and the low position, favorable for further flooding, at present prevent the economic utilization of most of these muck lands.

The largest areas of bog soils under cultivation in Puerto Rico are those classified as Peat which, under efficient management, yield from 35 to 45 tons of sugarcane per acre in regions where the precipitation fluctuates around 75 inches annually. Large tracts of peat occur around Loíza and 
Carolina, and are relatively free from harmful alkali salts. There is a fairsized area west of Cataño extending around San Juan Bay and in strips alongside Caño Martín Peña to Lago San José. Other areas of Peat are found in the east coast around Ensenada Honda and in the South around Puerto Jobos. Areas of the shallow phase are found east of San Juan and in close association with typical Peat soil.

Reparada and Ursula are the two organic soils of arid and semiarid Puerto Rico. They both occur in the southern and southwestern coastssouthwest of Ponce, near Caleta de Cabullón, in Punta Guayanilla, south of Central Rufina, in Punta Tocón, southwest of Lajas, and in other places of similar ecology. They are both subject to inundations during high tides. If drained, and if the salts are washed off, sugarcane grows well on these soils. Yields of 30 to 35 tons per acre have been reported. The area now under cultivation is very restricted; the majority of the lands being very salty. The Reparada soil covers an area over 2,500 acres, about 9 percent of the total organic soil area of Puerto Rico, and the Ursula more than 1,000 acres or 3 percent. Both of these soils occur in the extremely dry region of southern Puerto Rico, where rainfall never surpasses the 25- to 35-inch level. Because of their low geographical position they receive waters from the uplands nearby and from the Caribbean Sea, which causes a nearly constant waterlogged condition. This accounts for the fact that the vegetation is not typical of the arid zone where these halfbogs occur. The combination of hydrophytic and halophytic plants which thrive on these areas is rather an expression of local soil conditions than of the zone as a whole.

\section{MATERIALS AND METHODS}

The distribution of the organic lands of Puerto Rico was determined from the maps prepared in connection with the Soil Survey of Puerto Rico (11). Samples were taken at several sites following the technique of Cline (4). They were passed through a $2-\mathrm{mm}$. sieve. Undisturbed soil cores were also taken for bulk density determinations.

Conductivity measurements were done in 1:2 soil-water suspensions by using the standard solu-bridge. Bulk density was determined by drying a sample of known volume in an oven to $105^{\circ} \mathrm{C}$. The picnometer was used for specific gravity measurements. The total porosity was calculated from the well-known relation between bulk density and specific gravity.

\section{CHEMICAL PROPERTIES}

No organized effort has been made to study the chemical nature of the organic soils of Puerto Rico. Experience in other areas seems to indicate that, when drained, they are capable of producing a few crops successfully 
without appreciable expenses in fertilizer applications. A rational program of fertilization must be established, if profitable yields are to be expected.

Chemical data, as adapted from Bonnet (3), are presented on table 2. The reaction of the soils studied range from acid to alkaline, according to their climatic region. On the percentage basis they seem to be well supplied with nitrogen, and available phosphorus and potassium, and are quite high in available calcium. However the organic soils contain less total nutrients than the average mineral soil because of their lower weight per given volume of soil.

TABle 2.-Chemical data for the surface layer of some organic soils of Puerto Rico

\begin{tabular}{|c|c|c|c|c|c|c|c|}
\hline \multirow{2}{*}{ Soil type } & \multirow{2}{*}{ Location } & \multirow{2}{*}{$\mathrm{pH}$} & \multirow{2}{*}{$\begin{array}{l}\text { Total } \\
\text { nitro- } \\
\text { gen }\end{array}$} & \multirow{2}{*}{$\begin{array}{l}\text { Organic } \\
\text { matter }\end{array}$} & \multicolumn{3}{|c|}{$\begin{array}{l}\text { 1-percent citric acid } \\
\text { solution }\end{array}$} \\
\hline & & & & & $\mathrm{P}_{2} \mathrm{O}_{5}$ & $\mathrm{CaO}$ & $\mathrm{K}_{2} \mathrm{O}$ \\
\hline & & & Percent & Percent & Percent & Percent & Percent \\
\hline Peat & $\begin{array}{l}\text { Aguadilla-Maleza Alta, } \\
1 \mathrm{~km} \text {. North of San An- } \\
\text { tonio }\end{array}$ & 8.5 & 0.24 & 一 & 0.012 & 0.932 & 0.043 \\
\hline Saladar muck & $6 \mathrm{kms}$. East of Toa Baja & 5.1 & 1.54 & 51.3 & .024 & .638 & .081 \\
\hline Reparada clay & $\begin{array}{l}35 \text { spaces West of Haci- } \\
\text { enda Reparada }\end{array}$ & 8.1 & .29 & - & .021 & 2.350 & .011 \\
\hline Ursula clay & Ponce area & 8.7 & .28 & - & .016 & .847 & .035 \\
\hline
\end{tabular}

TABLE 3.-Specific conductance of the surface layer of some organic soils of Puerto Rico

\begin{tabular}{|c|c|}
\hline Type & Conductivity (mhos. $\times 10^{-5}$ at $25^{\circ} \mathrm{C}$ ) \\
\hline Peat. & 2,100 \\
\hline Peat, shallow phase $\ldots \ldots \ldots \ldots \ldots \ldots \ldots$ & 2,250 \\
\hline 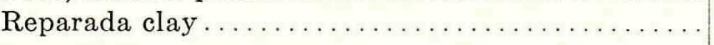 & 2,400 \\
\hline
\end{tabular}

In table 2 it may be seen that the organic matter of a sample of Saladar muck accounts for more than half of its total weight. Studies of peat soils near San Juan area indicate that their organic matter content fluctuates between 20 and 28 percent (9).

Table 3 gives values for specific conductance in the surface layer of some organic soils of Puerto Rico.

The content of salts is very high indeed as indicated by the conductivity values given in table 3 . However, such is not the case for all organic soil areas. The extent to which salinity problems may complicate the reclamation of Puerto Rican Bogs and Half-Bogs remains yet to be determined.

\section{PHYSICAL PROPERTIES}

Table 4 shows that the organic soils are very light in weight. In three instances, bulk density values are below $1.00 \mathrm{gm} . / \mathrm{cc}$. Mineral soils usually 
show higher values which increase with increases in the proportion of sand. Values for total porosity show considerable variability. They fluctuate from nearly 60 to almost 70 percent, which are high as compared to values for the average mineral soil.

Moisture studies indicate that peat soils around the San Juan area, as a rule, contain about 45 percent of water by volume at field capacity (9). Those values are higher than the corresponding ones for mineral soils and indicate that bog soils have a high water-holding capacity. Nevertheless, their available water may be even less than that of mineral soils, because wilting occurs at a very high moisture content. Plants have been observed to wilt permanently even when the soil still had moisture amounting from half to three-fourths of their total water retaining capacity. It seems that water is retained too strongly and is to a large extent unavailable for plants.

TABLE 4.-Bulk density and porosity of the surface layer of several organic soils of Puerto Rico

\begin{tabular}{|c|c|c|}
\hline Soil type & $\begin{array}{l}\text { Bulk density } \\
(\mathrm{gm} . / \mathrm{cc} .)\end{array}$ & $\begin{array}{l}\text { Porosity (percent } \\
\text { by volume) }\end{array}$ \\
\hline Peat. . & 0.79 & 59.25 \\
\hline Peat, shallow phase.. & .99 & 62.98 \\
\hline Tiburones muck. & .87 & 68.61 \\
\hline Reparada clay..... & 1.06 & 59.97 \\
\hline Ursula clay............ & 1.10 & 58.38 \\
\hline
\end{tabular}

\section{OTHER CONSIDERATIONS}

The drainage of the Caño Tiburones is already under way and will make available for cultivation about 5,600 acres of land at an approximate total cost of $\$ 1,500,000$ or about $\$ 267$ per acre (10). Bartel estimates that drainage of large areas of 500 acres, or more, will cost under $\$ 300$ per acre, while that of smaller areas will cost around $\$ 500$ (2). In all probability the cost of draining the coastal swamps and the leaching of the toxic salts, where feasible, will be costly, but Puerto Rico cannot afford to leave any area unreclaimed that may increase to any extent-no matter how limited it might seem - the arable lands of the Island. The Bogs and HalfBogs after being drained and leached of harmful salts or reclaimed with chemicals if necessary, will provide a considerable area of land that can be adapted to the intensive cultivation of cash crops, such as sugarcane and vegetables. High yields of truck crops have been obtained in other areas. A good cane tonnage has been obtained in Puerto Rico in the limited acreage of these soils fit for agricultural operations (11). It can reasonably be expected that higher yields can be obtained after draining, if a truly scientific approach is made toward the utilization and efficient management of these lands. 
The lowering of the ground water table of cultivated organic soils will eventually lead to the subsidence or settling of the land. Even at the starting point, there must be a conservation program to reduce or prevent losses of soil in muck lands. A sound program of fertilization should be developed at an early date, to keep the organic soils productive for a long time, because their natural fertility will only last a short period. A detailed program of research should be conducted to determine the most profitable and efficient management of peat and muck lands in Puerto Rico.

\section{SUMMARY}

There are more than 25,000 acres of organic soils in Puerto Rico, of which approximately 10 percent are under cultivation. They occupy very low topographical positions and in many instances brackish waters affect the profile. They were formed from the accumulation of leaves, twigs, roots, and other materials in lagoons and bays. The characteristic vegetation consists primarily of mangroves associated with other hydrophylic plants. Tiburones muck and Saladar muck make up more than 50 percent of the total acreage of Puerto Rican organic soils. These soils are generally well supplied with humus and nitrogen. Although they seem to be well supplied with calcium, and available phosphorus and potassium, it should be remembered that they contain smaller total amounts of these nutrients than the average mineral soil, because of their lighter weight per unit volume. From the physical point of view they seem to be well adapted to cultivation and rather easy to handle, if a sound program of management and conservation is followed. In cultivated areas yields of 45 tons of ratoon cane per acre have been obtained under the local management methods of the region, without a precise knowledge of the properties of organic soils, which probably require more specialized techniques to attain maximum yields and higher quality crops. The total cost of draining the marshes, where practicable, as well as of getting rid of the harmful salts, if present, will be high, but its beneficial effect on the economy of Puerto Rico can be far reaching.

\section{RESUMEN}

En Puerto Rico hay más de 25,000 acres de terrenos orgánicos de los cuales un 10 por ciento aproximadamente, se encuentra ahora bajo cultivo. Estos suelos están a niveles muy bajos y en muchos casos el agua del mar los afecta adversamente. Se formaron de la acumulación de hojas, ramas, raíces, y otros materiales en lagunas y bahías. El mangle y otras plantas hidrofílicas constituyen la vegetación típica de esos terrenos. Más de la mitad del área total de los suelos orgánicos de Puerto Rico pertenece a las series "Tiburones muck" y "Saladar muck." Estos suelos orgánicos son 
generalmente ricos en humus y nitrógeno y tienen un alto por ciènto de calcio, fósforo y potasio asimilables, pero debido a su bajo peso por volumen tienen menores cantidades de estos nutrimentos que el suelo mineral típico. Son fáciles de cultivar pero es necesario manejarlos apropiadamente. Bajo nuestras condiciones locales, y sin técnicas especiales de cultivo, estos suelos han llegado a producir hasta 45 toneladas de caña por acre. El costo total de desagüe de estos suelos y del lavado de sales que habría que hacer en algunos casos, será alto, sin embargo, su efecto en la economía del país puede ser muy favorable.

\section{LITERATURE CITED}

1. Alway, F. J. Agricultural value and reclamation of Minnesota peat soils. Minn. Agric. Exp. Sta. Bul. 188. 1920.

2. BARTEL, F. O. A preliminary report on the drainage of mangrove swamps and other marshy lands in the coastal region of Puerto Rico. Res. Bul. on Agric. and Livestock No. 3. P. R. Dept. of Agric. and Commerce. 1943.

3. Bonnet, J. A. Chemical data of Puerto Rico soils. Res. Bul. 1, Univ. of P. R. Agric. Exp. Sta. 1941.

4. Cline, M. G. Methods of preparing and collecting soil samples. Soil Se. 59: 3-5. 1945.

5. Cruz-Monclova, H. Estudio sobre la reclamación de los terrenos del Pueblo de Puerto Rico. Preliminary report to the Commissioner of Agriculture and Commerce of P. R. Files Univ. of P. R. Agric. Exp. Sta. 1942.

6. Dachnowski-Stokes, A. P., And Roberts, R. C. Saline peat profiles of Puerto Rico. Jour. Was. Acad. Sc. 24: 175-182. 1934.

7. Edelman, C. H. Soils of the Netherlands. Amsterdam. North Holland Publishing Co. 177 pp. 1950.

8. Harmer, Paul M. The muck soils of Michigan, their management and uses. Mich. Agric. Exp. Sta. Sp. Bul. 314. 1941.

9. Lugo Lopez, M. A. The moisture relationships of Puerto Rican soils. Unpublished doctoral thesis. Cornell University Library, Ithaca, N. Y. 1950.

10. Muñoz Morales, L., Dávila, N. C., And González, R. A. Informe sobre un proyecto de drenaje para el Caño Tiburones. Land Authority of P. R. 1947.

11. Roberts, R. C. and Party. Soil Survey of Puerto Rico. U.S.D.A. Series 1936, No. 9. Bur. of Plant Ind. in cooperation with Univ. of P. R. Agric. Exp. Sta. 1942.

12. Zerban, F. W. The salt marshes of the north coast of Porto Rico. Bul. 4 P. R. Sugar Producers Association. Exp. Sta. 1913. 